\title{
Nasopharyngeal Cancer pTis TNM Finding v8
}

National Cancer Institute

\section{Source}

National Cancer Institute. Nasopharyngeal Cancer pT is TNM Finding v8. NCI Thesaurus.

Code C132802.

Nasopharyngeal cancer with a finding of carcinoma in situ. (from AJCC 8th Ed.) 